E Q U I L I B R I U M

Volume 6 IsSue 1, 2011

IS S N $1689-765 \mathrm{X}$

\author{
Mestwin Stanisław Kostka \\ University of Finances and Management in Biatystok, Poland
}

\title{
After Crisis? - The Only Way: \\ Economics for Sustainable Development
}

JEL Classification Codes: $Q 01$

Keywords: economics, economic crisis, economic growth, sustainable development

\begin{abstract}
The aim of the paper is to justify why contemporary economics must be reoriented from the direction of Economic Growth to the direction of Sustainable Development. Human society is at a deadly curve. The Economic crisis is only one slice of Gordon's Knot of Crises of our Civilization. The Economy is facing system challenges without precedence. Reasons for this situation are different fetishes of present positive and normative economics. The author explores the main aspects of diagnoses, prognoses, analyses, assessments, and present solutions concerning economy. Of fundamental importance are: the essence of the global crisis, new challenges facing Western civilization in the near future, and fundamental misunderstandings in the proposed solutions of crucial problems. The one chance for an adequate solution to the critical situation is the Strategy of Sustainable Development. In Poland this strategy is absent in mainstream economics as a theory of economy and as the foundation of rational policy. It concerns a very broad front of economic sciences and economic technologies. Economic academic education is also not adequate to the very serious situation facing graduates in the future. Consciousness, knowledge and abilities of economic professionals are good for the past, not for the nearest future. In Poland, an additional problem is a lack of common economic academic education in English. Present economics and economy must be verified with many original (not translated) settlements and conclusions concerning sustainable development from economics and from other sciences and from reality outside economy. Of crucial importance have been settlements and conclusions of ecology and of sociology on the basis of information technologies.
\end{abstract}




\section{Introduction}

In spite of all the successes of our civilisation, the huge area of the Earth is a picture of inequality, injustice, poverty, destitution, depression, waste of resources and many other undesirable features and processes of the Human World. The eternal fundamental problems of the Human Being have still been unresolved. We simplify the seriousness of the present situation of MAN, if we concentrate only on the discussed issues of economic crisis ${ }^{1}$.

Economic problems that have been at present discussed are only the tip of the iceberg on the road of Humanity's development. Human society is at a deadly curve. The economy is at the face of system (See: Bertalanfy 1951) challenges without precedence.

The essential chance for an adequate solution to the present problems is the Strategy of Sustainable Development (World Commission on Environment and Development 1987, pp 2-10). In spite of the fact that the term sustainable development has been used since 1987, up to now this term is known and accepted only by a minority of common people (voters), and policy decision makers on international, regional and local scales. This should be changed, with the term becoming clearly connected to the concepts of economy and economics.

The main aim of the paper is the justification that temporary economics must be reoriented from the direction of Economic Growth to the direction of Sustainable Development.

Settlements and conclusions of the paper are the results of long term research and other activities of the author in the field of interpenetration of: natural, technical and social sciences; science, technology, education and applications; ecology, sociology, law, economics, management, decision making, computer science, information technology; mining, agriculture, forestry, fishery, water management, spatial economy, finances, management of the firm, tourism, nature \& environment conservation. This paper is only focused on making a contribution about economics within a much wider fundamental problem of contemporary times.

\section{Market economy}

At present, so called developed nations are organised as a Market Economy. Most important is the concept of market - something that joins all the separate

\footnotetext{
${ }^{1}$ Author uses italic maybe too often. The reason is that the marked terms have many definitions.
} 
concepts of economy of Anglo-American Civilisation. ${ }^{2}$ Many nations are still organised as Non-Market Economies. Non-Market Economy has a history of many thousand of years.

The beginning of Market Economy has been joined with the start of capitalistic relations among different entities of the economy: persons, households, enterprises, institutions, organisations, municipalities, regions, and countries. There is a paradigm, that all these entities are existing in conditions of free competitiveness, private property of economic resources, and limited government involvement.

In Market Economy, households and businesses largely make consumption, production, and resource allocation decisions in a system of markets. Like every system, the Market System consists of countless market elements: subjects of market, economic resource market, market of services, market of products, market of money, ... market of know- how, market of possibilities, market of will, ... market of consumers, market of producers, market of decision makers, etc. As in every system, in Market all elements have been joined in given relations. These are the market relations. There is time, when a market begins to hide too much of this which is more important for Human Being than a market.

Since the creation of capitalistic relations among the mostly creative and enterprising entities, there is an acceleration of variables of consumption, exchange, production and distribution. But not only this. This acceleration concerns almost all other variables, we use to describe economy: households, enterprises, public institutions, $N G O s$, resources, products, services, demand, supply, costs, incomes, wages, interest rates, profits, deposits, debts, GNP, GDP, etc. A very long list of these variables and their definitions we can find in economic dictionaries and indexes of handbooks of economics.

The richer the person, household, and firm are, the more developed municipality, region, and country are - the greater the fascination with the results of competition among different subjects of economy, they are directed by the invisible hand of the market. From the interior of the developed world the Market Economy seems to be the highest level of results of economic practice and theory. More detailed observations, analyses, comments and settlements are drawing a beautiful picture of Market Economy with different cracks and stains. Very interesting example of details of Market Economy is Las Vegas.

${ }^{2}$ Author uses this concept as a synonym of market economy. Present market economy is a result of economic thought whose mainstream began in Great Britain in the XVII century, and is developing first of all under the influence of UK's and USA's economy and economics. 


\section{Las Vegas as a case study of market economy}

More detailed information concerning Las Vegas comes from the book, edited by D. Littlejohn (D. Littlejohn (ed.), 1999), and from the personal experience of the author. People mean different things when they refer to Las Vegas. The term Las Vegas means two million people living, with a few million tourists visiting each year, in a dry desert surrounded by treeless mountains in the south part of the State Nevada, USA. Very near are the Colorado River, Hoover Dam, and Lake Mead. Not far is the Great Canyon, Arizona, California, and Los Angeles.

As a town (socio-economic system) Las Vegas began life in 1905, when the sale of lots of railroad-owned land started. The rapid development of the town began after World War II. Almost unprecedented boom is the phenomenon of the last decade of the twenties. At that time Las Vegas was one of the fastest growing urban areas in the United States. In 1995 more then one million people called Las Vegas home. In 2009 Las Vegas (metropolitan) reached 2 million inhabitants. (Estimates of Population...2010)

For most people, the word Las Vegas denotes the Strip - a four-mile stretch of Las Vegas Boulevard South. There are about 60 casino-hotels with about 200,000 rooms, scores of restaurants, meeting and convention halls, show rooms, spas, arenas, shops, more than 500 acres decorated space. Because of the Strip, Downtown Las Vegas is one of the best known cities in the world.

The dominant industry of Las Vegas is casino gambling or Gaming Industry. Others industries: servicing gamblers, construction, transport etc., are secondary. This industry "...is divided among about a dozen owners or co-owners of major Strip hotels and a few locally based or family-owned off-Strip companies, backed up by slot-machine manufacturers and similar adjuncts..." (D. Littlejohn (ed.), 17, 1999). This industry is ubiquitous, and its influences are visible in all elements of Las Vegas socio-economic system.

Las Vegas's Strip and Downtown seem to be examples of special "Eden" of the Market Economy. Millions of people are coming here every year with money and for money. Only a very little number of them leave Las Vegas with more money than they had before coming here. Their money has enriched Las Vegas: its inhabitants, households, enterprises, institutions, and organisations, but only very little number. Las Vegas' economy is growing, and even developing. Nevada's economy is growing, and even developing..., too.

More detailed observations are drawing this beautiful picture of Las Vegas with different cracks. Beyond the Strip and Downtown there are a lot of individuals and households on very low level of satisfying their basic needs, and even very poor, hungry and thirsty. Rates of alcohol consumption, cirrhosis of the liver, automobile accidents per mile driven, abortions, teen pregnancies, birth to unmarried mothers, suicide, percentage of smokers, death from lung cancer, coronary artery disease and cardiac arrest, in many cases are the highest or very 
high in the USA. Las Vegas had the highest total crime rate and the highest rate of crimes against property among All-American cities with more than 250,000 people. Nevada's bankruptcy rate in 1997 was the forth highest in USA. Very sharp crisis concerning water and air resources is visible.

The detailed history of Las Vegas's development in $20^{\text {th }}$ century is proving unusual acceleration of main economic variables. Here have been concentrated very creative and enterprising people, who had discovered the new resources, and can use them much better than in other economic systems. Here are very visible unusually effective investments in the world of money. From the point of view of economics Las Vegas is:

1. Unusual place of concentration of very diverse group of economic resources:

- land: characteristic placement, characteristic climate, desert, water from artesian springs, water and energy of the Colorado River, the Grand Canyon, primarily very cheap lots for different investments;

- labour: very high qualified specialists e.g. natural scientists, first of all geologists, and engineers, economists, lawyers, managers, and finally very cheap workers;

- capital: modern machines and facilities, relatively cheap energy and row material for construction, Hoover Dam, Lake Mead, and unimaginable resources of money for investments;

- technology - the latest world - scale technologies;

- entrepreneurship - almost the best in the world, supported exceptional absoluteness of owners of money reSources:

Such concentration of economic resources must give rise to something unusual, as Las Vegas is. More: from the point of view of Las Vegas's Strip and Downtown the problem of scarcity of economic resources is almost invisible. It doesn't concern the rest of Las Vegas - its life beyond the Strip. In the whole world details of the real economic variables and a whole economic situation outside the Strip (ca 1.8 million of people!) are almost unknown.

2. An unusual means of consumption. At last Las Vegas is a "Rome" and "Mecca" as a place of pilgrimage of money believers. There is a concentration of very deep dreams, desires and wants of common and uncommon people, who are the best "kids" of "Mother" - Market Economy: entrepreneurial, strong, effective, relatively not poor, and requiring money. Here is concentrated characteristic demand - characteristic, because this demand concerns the Las Vegas's Strip and Downtown. Fundamental needs almost do not exist.

3. An unusual centre of production of goods and services, which are adequate to the unusual demand. A response to this demand is an adequate supply: hotels, casinos, places and facilities of mostly exquisite amusements.

4. An unusual part of world of money. Here is concentrated money in all its physical forms and in all forms of exchange value. Las Vegas is one of 
the most important junctions of trails of money flows in global scale. On the one hand, it is one of the centres of unimaginable squandering of money. On the other hand, Las Vegas is one of the centres of unimaginable facilities, which serve "production" of money. It is a centre of mostly effective systems of multiplication of coins, banknotes, and sums of money on personal and co-operative accounts of owners and co-owners of casinos.

5. An unusual market. Unusual, because it is a huge market of what is outside the fundamental needs of human beings - wants, desires, and dreams.

6. Las Vegas is an unusual crossing of fundamental economic variables. This crossing is especially important for political economists. A large number of political economists concentrate only on details of the whole economy. These details do not show the complete system - not only market economy, but economy and socio-economic system as a whole.

7. Las Vegas is a Great Question Mark concerning the future of Market Economy and Humanity.

8. Las Vegas is an unusual mirror which is reflecting the essence of Market Economy.

Las Vegas forces an urgent answer for the questions: where is the Market Economy going faster and faster, and who or what is directing the Market Economy? These questions concern not only the Market Economy. These questions are concern the Man as a subject, not as an object of Market Economy.

\section{The god of market economy}

The people who are creators, subjects and objects of Market Economy are very similar to the Moses' people, who were going to the Promised Land. There was a God, and there were the Fetishes. The Market Economy is a fact. It is not a problem of Faith. Economics belongs to Knowledge, not to Faith. But one source and foundation of Knowledge is Faith.

Almost in every form of Faith, God is a Great Secret - of the Past, of the Present and of the Future. The believers could or must believe, non-believers do not. The future of a Market Economy is a great secret, too. It is important where Market Economy is heading for, but nobody knows what and where it is. Commonly it is known as welfare or wealth. In some circles of people it is called Freedom, Equity, and Economic Justice. At last for very large number of people the only God of their sense of life and of their activity is Survival.

For common people it is very difficult to believe in something, it is a Great Secret of unimaginable Promised Land. In Market Economy, too. It is so, because common people are not thinking and acting in very wide limits of space and time. They are interested first of all in facts, things, phenomena and processes which are very concrete and very close to their personality, families, 
households, enterprises, municipalities, regions, countries. Because of this, the common people have been interested first of all in self-interest and in material forms of consumption, production, exchange and distribution. Especially they are very interested in different elements of the world of money: coins, banknotes, checks, credit cards, wages, salaries and other money gratifications. They are very interested in other valuable things as: pieces of gold, diamonds, lots of land, buildings, real estates, machines and tools, too. But it is a problem not only of common people. It is a problem of economists, too.

As was mentioned, the final goal of the Man, in the Market Economy, is $a$ Big Secret. It could be commonly accepted, that majority of people are not against the Moses' Decalogue. There are other commonly accepted final goals of Human Being, synthesised by the concept of HUMANITY. To put it simply, it may be accepted that in reality - in the frame of knowledge, experience - not in Faith - the highest, mostly valuable, and commonly accepted final goal of human activity is a MAN. This is the GOD of Market Economy, too. All others must be subordinate to Him. This God is sometimes hidden by different fetishes.

\section{Fetishes of market economy}

...Fetish is an object believed among a primitive people to have magical power to protect or aid its owner; a material power object regarded with superstitious or extravagant trust or reference or obsessive devotion... (Webster's Dictionary, 1983, p. 458) . The concept of fetish is synonymous to mistake, error, fault, stun, stupefy, benumb, cheat, swindle, fraud, lie.

Economists almost commonly accept that very important goals of economic activity are needs, wants and desires. In other words, there is a problem of very widely understood consumption. It covers the problem of over-consumption, consumption of cigarettes, consumption of drugs, consumption of goods and services, which destroy the Man and Humanity. It seems that a majority of contemporary challenges is a result of over-consumption. Up to now, the Market Economy is serving not only consumption, but first of all over-consumption. More precisely, there is a problem that Market Economy is serving dreams, wants and desires too much, but fundamental needs of the people too little. To summarise, there is a problem of fetish of over-consumption.

Commonly accepted is production of goods and services, which are demanded by those, who have money. In this way, the Market Economy's decisionmakers are concentrating on growth of production and increasing GDP. But this is a one problem. The other problem is that not every production serves the Man and goes to the final goals of the Man.

What? How much? How? To Whom? - to produce. But - for the Man or against the Man? No doubt that in Market Economy too much is produced 
against the Man: guns, cannons, tanks, fighters, bombers, warships, rockets, ammunition, bombs, narcotics, waste, stupid books and films, etc. In too many cases production starts to to be, and is a fetish of Market economy. In this case there is a problem of fetish of over-production.

Resolving of problem of fetish of over-production is very closely joined with the problem of GDP. The wealth and welfare of very large number of individuals, households, enterprises, communities, regions and countries depend on the over-production, and even on production against the Man. Which community will agree with lowering of GDP, and other money outputs, when their high standard of life depends on this kind of over-production? In this case profits and GDP are fetishes.

Many economists believe that the only and the best tool of realising all purposes of Market Economy is an invisible hand of the market. Other economists hold the opinion that only government's ruling and interventions in Market Economy guarantees its harmonic existence and development. Many economists state definitely that only a private ownership of means of production guarantees the best future of society. There are economists who believe only in interest rates. Others concentrate their activity on lowering inflation.

It is very difficult to find somebody who is not concentrating on conquering money. In Market Economy the existence of individuals, families, firms, institutions and organisations without money is almost not possible. Because of this, in Market Economy there is a permanent and without scruples battle for money. In this case, the Market Economy could be called an element of the Nature without a Human Being (Homo Sapiens L.). In Nature there is a mortal battle for means of Survival. In Market Economy is a mortal battle for Money. It seems that MONEY is a crucial Fetish of present Market Economy. There are some ways of conquering money. The easiest seems to be a robbery or gambling.

The problem of fetishes of Market Economy is not new. It is an eternal problem of HUMAN CHOICES. The Man's problem is if consumption is rational or irrational. What kind of consumption is rational, and what is irrational? The same concerns production. In this case, we must come back to the roots of humanity. First think then do, or: first do, then think? The Man's answer is evident. Not evident is the answer of common people, decision-makers of economy, and... economists.

\section{The essence of the global economic crisis}

The global economic crisis was signaled by leading representatives of economics very early. T. Malthus (1798), K. Marx, H. George (1879), W. Kapp (1962), K. W. Boulding (1966) were prominent. In 1972 evidence for it was given by the authors of the First Report of the Club of Rome Meadows D.H et al. 1972). At 
present there is a growing number of authors seriously engaged in positive and normative aspects of the global economic crisis. They have been analysing disabilities, distortions, faults, mistakes, errors and other negative results of the socalled Market Economy, and are looking for adequate solutions. In spite of this, results are problematic - solutions are short-term and particular.

The main reason for the Global Crisis seems to be the existing Model of Euro-American Civilization. The main processes of this model are: exponential Growth of Consumption, exponential Growth of Production, exponential Growth of Exploitation of the Whole System of Gifts from God (natural resources), exponential Growth of Waste. Very essential is that there is a rapid growth of variables of social welfare. It is a pity that it concerns small minority people. At the same time, there has been a rapid growth of social poverty and waste. It concerns more and more the majority. There are more and more economic and political institutions which have been created and developed to support the existence of the mentioned model.

The acceleration (+/-) concerns almost all variables we use to describe economy: households, enterprises, public institutions, relations among them (socioeconomic relations), resources, products, services, demand, supply, employment, costs, incomes, wages, interest rates, profits, deposits, debts, GNP, GDP, etc. A very long list of these variables and their definitions can be found in economic dictionaries and indexes of handbooks of economics.

Since the $18^{\text {th }}$ century, there have been very symptomatic changes of two groups of aggregated economic variables. One group represents all variables which concern the Man and the results of Human activity (products, services and wastes). The second group is created by matter and energy of Nature (gifts of God). Qualitative and quantitative aspects of these changes in the course of time are presented in Fig.1. The human beings and the results of human activity in the last three centuries are going faster and faster to... (to stars). At the same time, the Gifts of the God are going faster and faster to... zero.

Such crossings are eternal. But they were of local and regional character. Now, there is a Global Crossing - crossing the critical point of human existence and development. Such a situation on a global scale has never been seen in the whole history of mankind. The presented relation seems to be the essence of global economic crisis. What is more - this crossing seems to be the essence of the whole Crisis of Humanity. It is crucial challenge of our time. This crucial challenge is a system of challenges.

\section{Challenges of the near future}

In the $21^{\text {st }}$ century the Humanity is at the face of unusual global challenges. There are a lot of challenges concerning existence, survival and development of the MAN: 
- explosive growth of the hungry, homeless, poor, desperate, fanatic individuals and groups of people;

- growing scarcity of resources of: clean air, pure water, productive soils and forests;

- exponential growth of wastes;

- global warming;

- more means of mass extermination in the hands of extremists and terrorists;

- growing reality of global confrontations;

- reality of destruction of present Civilisation because of the stupidity, shortterm thinking and self-interest of some decision makers.

A detailed list of real challenges has no end. MAN is facing a system of challenges, the Gordon's Knot - Global Crisis, concerning Homo Sapiens L. This system consists of countless elements, and countless and very dynamic number of relations. The contemporary global economic crisis is only one of the slices of the Gordon's Knot of Crises of our Civilisation.

We are observing a very laborious process of resolving the global economic crisis by the main players of the global economy. Real effects are problematic and controversial. Assessments have different points of view and different solutions. As we know, Alexander the Great had resolved his Gordon's Knot very simply. This solution is rather impossible in the case of the present Gordon's Knot. Nobody has ever resolved problems concerning such challenges. In solutions very important is not only the essence, but first of all, reasons for this situation.

All problems concerning unprecedented challenges are of cross-sectoral nature and have to be tackled in an interdisciplinary way. They have international, regional and local aspects and concern relationships inside and between sectors. Different disciplines of science, technology and real actions need not a development of competitiveness, but very effective partnership in action.

All researches concerning the reasons for present system of crises and new challenges of Humanity point to: consumption, production, exchange and distribution of resources, products and services, as crucial. This means that all main reasons for Crisis are sticking in economy and in its theory - economics. On the other hand, the rational solutions of difficult problems in any case need the choice. In other words: the only way to solve the very difficult and complicated problems of the existence and development of Man's Population is rational activity. It is a domain of economy and economics. But they must be adequate to future, not to past problems.

It is essential that in Polish, a lot which concerns economy and economics, in many cases does not correspond with original English information. In Polish handbooks and academic education of economics there is a lot of information, which does not correspond with main settlements of economics in English. Moreover, in Polish economics there is a lack of information, which has been 
essential in more developed economies. It applies to the concepts economy and management, too. Important are definitions. Detailed analyses of many translations show essential differences. Because of this, it is necessary to review some settlements concerning economy and economics.

\section{Fundamental concepts}

A reason for the different problems, both in nature and in society, are the concepts used to create the right language to correctly reflect the facts of physical reality. If the concepts are not adequate as tools of description, and of explanation of the phenomena and processes of reality, it is very easy to make mistakes when altering this reality by human activity. The indistinct use of many terms inevitably produces ambiguity. Different writers give the same term different meanings, and the same writers use a term in different ways. A more detailed analysis of the controversy concerning the terms economy, management and economics, has caused the conclusion that a lot is linked to the idea of the eternal Bible's Babel Tower, which has been built by very wide circles of economists, and not only.

In Webster's Dictionary the economy is defined as “...the thrifty and judicious use of money or goods; an instance of this; the economic system of a country...". Because in the same Dictionary the term economics is defined in a separate entry, it is obvious that these two terms are not the same. There are many prominent Polish authors and serious decision makers, who have been treating these two terms as synonyms in one concept - ekonomia. The terms, economy and economics must be consequently treated separately. Polish terms, gospodarka and gospodarowanie in English have corresponding concepts i.e. economy and management. It means that both English terms are synonyms of the Polish term zarzadzanie. In Polish, there is an essential difference between zarzadzanie as administracja, and zarzqdzanie as gospodarka, gospodarowanie.

Economy. The term economy is a term concerning sensorial (physical) reality. This reality we can: see, hear, touch, smell, taste. All concern: given borders of space, given limits of time, given forms of matter and energy, given ecosystems, given complexes of resources, given people with given needs, desires and wants. In economy there are real, physical people: men, women, children, youth, adults, seniors. These people can have documents that they are: students, married, experienced, unemployed, employed, soldiers, laborers, clerks, entrepreneurs, directors, ministers, congressmen, etc. They are living on a given: surface of the Earth, forested land, rural area, in mountains or at the desert. They are living in given: flats, houses, villages, municipalities, towns, regions, states. They are connected with given: minerals, soils, forests, seas, ecosystems, plant \& animal populations, other people, etc. At last, there are people, who are directly con- 
nected with different things, phenomena, and processes. These, who are mining minerals, we call miners. These people, who are directly connected with fishing, we call fishermen. The other are: agriculturers, foresters, drivers, clerks, sellers, bankers, brokers, controllers, etc.

In economy, there are physical complexes of matter and energy: minerals, soils, plants, animals, rivers, seas, forests, rural areas, roads, plane fields, energy power plants, refineries of oil, shops, buildings, flats, ships, trucks, clothes, elements of food, etc. Some of them have been of natural origin (natural resources), others are results of human activity (products). Not all complexes of matter \& energy, things, phenomena, processes, but only given are economic reSources: Some of them are elements of raw material and half-products, some of them are means of production, some of them are tools and machines, some of them - elements of shelter, cloth, food. Some of them are non-commodities, some - commodities. These real things have been elements of the real sphere of: consumption, production, exchange and distribution of real goods and services.

There are different real, physical phenomena, which have essential influence on economy: climate, whether, rainfall, snowfall, flood, frost, dry whether, waterfall, flowering of fruit trees, fog, spring, summer, autumn, winter, smoking chimneys, traffic, manifestation of crowd of the people, battle, war, etc. There are different real, physical processes: changing of matter, flow of energy, evaporation, photosynthesis, accumulation of organic matter, erosion, production of food, production of bombers, selling of cloth, accumulation of US\$ of an real account in the bank, changing of banknotes, accounts of US\$ on EURO; etc. Elements of economy, relations inside economy and relations between economy and other elements of human environment, are real, reflected and informed by human senses. They are or they are not of concrete quality, quantity, utility, value...

Essential is a very rich and changeable structure of economy: spheres, branches, active and passive elements. Active elements of this structure are people: individuals, families, groups of interest, nations, households, enterprises, institutions, organizations, activities. Passive elements are: things, phenomena, processes, resources of land and capital, some purposes of activity, and some results of human activity. Elements of economy and relations among them are different in space and time, in their place, and functions. They differ in categories of their influence on given economy.

Do we know about economy what is essential, and what we need in given circumstances? Does an economist know the concrete part of economy, when in handbook of economics he/she has the information "resources have been outside interest of economics"? Economy is a reality. To this reality we can adapt, or we can change it. Rational Man can not agree that this reality ought to be managed by "invisible hand of the market". The only way of solutions is rational activity - not only physical, but first of all mental. There is a need to have not only argu- 
ments of power, but power of arguments first. The latter belong to economics, to theory of economy, management and to decision making based on economics.

Economics. Economics is defined variously. ${ }^{3}$ Generally, it is a science. The objective of economics is to understand the real world and to be able to predict the results of certain events. The main aim of economic analysis is better understanding of the factors at work in the economic life of society. Its fundamental problems are scarcity of resources, choice, opportunity costs. Positive and normative analyses and conclusions are of crucial importance. Many authors express the opinion that there is no difference between economics and political economy.

Essential is macroeconomics - a branch of economics which deals with the economic system as a whole - an overview on real economic world and on different partial problems of economics and economy.

Very important are three broad objectives of economics:

- efficiency - economics is concerned with the ways and means of scarcity and with making the optimum use of limited resources;

- equity - acceptance of the social and economic desirability of a more equitable or fairer distribution of wealth. Modern society is regarded as having obligations to its poorer members, and economics has the responsibility of suggesting ways of achieving a more equitable distribution of wealth;

- stability - economic policy must prevent the occurrence of alternating booms and slumps, and the avoidance of them necessitates a clear understanding of the way in which the complicated economic system works and the reason for its failure to progress smoothly in the past.

In post-communist countries the economics is not adequate to real challenges of these countries. Of crucial importance are fundamental mistakes in translations of English economics into national languages. Many original English concepts and theses past translations in other languages have other sense from the original. This concerns, first of all, one of fundamental concepts of contemporary time - sustainable development.

3 ...economics - a social science concerned with the production, consumption and distribution of goods and services. Webster's 1983.

...Economics is a science which studies human behaviour and how the scarce resources, which have alternative uses, are distributed in attempting to satisfy the infinite needs and wants of mankind... (D. McCarthy, K. Spencer; 1992, pp. 12-14).

...Economics is the study of how people choose to allocate scarce resources to satisfy their unlimited wants... (A. R. Thompson, Economics, Addison-Wesley Publishing Company, 1985, pp. 6-7). 


\section{Sustainable development}

The financial and economic crises and other challenges have drawn much attention to fundamentals of present development. A lot of evidence indicates that the main reason for mentioning Gordon's Knot of Crises, is a common activity oriented at economic growth as the only basic precondition of real development ${ }^{4}$. Economic growth is still defined as the major objective and generally not questioned. Present economic growth is a short - term one, and at the expense of future generations, the poorest people, nations, countries, regions and municipalities.

How to meet the needs of present generations without compromising the ability of future generations to meet their needs? (Bachmann, 2007) This question was moulded into the concept of sustainable development (SD) in 1987. (World Commission on Environment and Development, 1985). Since 1990 a large number of initiatives have been carried out throughout the world to attempt to raise awareness of sustainable development and promote initiatives to achieve it. In spite of this, 24 years after the Our Common Future was published, 19 years after Agenda 21 was produced, and 9 years after the world's commitment towards sustainability was reiterated in the Johannesburg Declaration, the need to make the information on the approaches, methods, projects and initiatives aimed at fostering the cause of sustainable development known, is as pressing as ever. Sustainable development became a fundamental objective of the EU, too. Despite important achievements in implementing the EU Sustainable Development Strategy, unsustainable trends persist, ranging from climate change to the ageing of societies in developed countries and a widening gap between the rich and the poor in the world.

Essential step of EU Sustainable Development Strategy is the Green Economy Initiative $e^{5}$. It is designed to assist governments in "greening" their economies by reshaping and refocusing policies, investments and spending towards a range of sectors, such as (1) clean technologies, (2) renewable energies, (3) water services, (4) green transportation, (5) waste management, (6) green buildings and (7) sustainable economy.

In Poland's Constitution (Constitution of Poland 1997, Art. 5) sustainable development is equally important as its national interests and the security of the country. In 2000 the Council of Ministers signed the Poland 2025 - Long-term

${ }^{4}$...The nature of this crisis situation has led to a questioning of the hegemony of economic growth as the prerogative policy objective... G. Berger \& N. Gjoksi: Linking economic growth and sustainable development: Strategies, initiatives and activities on the international, EU and national level. www.sd-network.eu March 2010.

${ }^{5}$ Greening the economy refers to the process of reconfiguring businesses and infrastructure to deliver better returns on natural, human and economic capital investments, while at the same time reducing greenhouse gas emissions, extracting and using less natural resources, creating less waste and reducing social disparities. 
strategy for sustainable development. The problem is that even though sustainable development is mentioned in the Constitution, it does not automatically mean that there is a growing public awareness of the issue. In practice, still there is a lack of complex approach..Despite the various projects being run at international level, a lot still needs to be done at regional and local level.

In Poland and for Poland of crucial importance are theses:

- ...in Poland unfortunately, sustainable development is often understood primarily in ecological terms and not as a model for coherent development and sustainable consumption habits...;

- ...in Poland - one of the few countries in the world which have introduced the concept of sustainable development at the level of the Constitution, it is difficult to find a reference to it in the political debate...;

- ...An average citizen does not know about the concept of sustainable development, nor does he or she have even the vaguest notion of it...;

- ...Solving social problems (the labour market, education, health protection, gender equality, etc.) is not associated with sustainable development...;

- ...there is no clear reference to sustainable development in other ministries or departments responsible for social and economic issues...;

- sustainable development ...requires profound changes in thinking, in economic and social structures and in consumption and production patterns in Poland... and ... must be seen as a new life style which can be combined with economic growth and welfare... (Kostrzewa, Piasecki 2009, pp.185$-197)$.

These are of fundamental importance for economic sciences and academic education. Any rational activity is impossible without taking into account the following problems: consciousness and knowledge of professionals, responsibility for the functioning of the economy, which must be sustainable.

\section{Conclusions}

The population of Homo Sapiens L. is at a deadly curve of its way to the future. This deadly curve is a system of crises of Humanity. The economic crisis is only one slice of Gordon's Knot of Crises of our Civilization. We are not after, but still in the course of crisis. Economy is at the face of system challenges without precedence.

New challenges have been the real problems. These problems change all main variables of real economic systems. These new problems and variables of economy are beyond the interest and of activity of mainstream economics. In this way, the economy is in the $21^{\text {st }}$ century, but its theory - economics still in the $20^{\text {th }}$, and in some cases even in the $19^{\text {th }}$ century. It concerns, first of all, economic researches and academic education. 
The separate system of problems is a Syndrome of Babel's Tower - in the whole sciences and in economic sciences, too. For example: specialists of macroeconomics do not understand micro-economists; managers are not accepted as economists and vice versa; spatial economy is not economy; etc. Misunderstandings concern crucial and fundamental problems of the present. Long discussions of economists with economists, economists with technologists; economists with managers, etc. belong to the deep past. But new challenges are of interdisciplinary character.

The Great Chance for limiting and liquidation of crises and their parts is all which is connected with the concept of sustainable development. In the author's opinion, that it is the only right way for the exit from crisis situation. But first of all, it must be implemented in consciousness, knowledge and real activity of representatives of mainstream economics. Economy without adequate economics is blind and could go off a precipice. Economics not focusing on economy, not verified by economy goes to Utopia. Economics without settlements and conclusions of: natural, social, technical, geographical, medical, and many other sciences is like Robinson Crusoe's Island. The direction to sustainable development is Our Common Future with the help of economy and economics.

\section{Literature}

Bachmann G. (2007), Catching a glimpse of future. In I. Niestroy (ed.) Stimulating informed debate - Sustainable Development Councils in EU Member States. A compilation of tasks, capacities, and best practice. EEAC Working Group on Sustainable Development.

Bertalanffy L. V. (1951), The General System Theory, Buman Biology, 23, 1951, and many later publications.

Boulding K. E. (1966), A Reconstruction of Economics, Science Edition, New York.

Estimates of Population Change for Metropolitan Statistical Areas and Rankings: July 1, 2008 to July 1, 2009. U.S. Census Bureau. 2009-04. http://www.census. gov/popest/metro/ tables/2009/CBSA-EST2009-05.csv. Retrieved October 26, 2010.

George H. (1879), Progress and Poverty. London.

Kapp W. K. (1962), The Social Costs of Private Enterprises.

Lange O (1949), Ekonomia, KiW, Warszawa, p. 9.

Littlejohn D. (ed.) (1999), The Real Las Vegas: Life Beyond the Strip, Oxford University Press.

Malthus T. R. (1798), An Essay on the Principle of Population, as it Affects the Future Improvement of Society, London.

Marx K., different settlements and conclusions

McCarthy D., Spencer K (1992), Modern Economics, Mentor Publication, p 12-14.

Meadows D. H., Meadows D. L., Randers J., Behrens W. (1972), The Limits to Growth, London.

The Economics of the Coming Spaceship Earth (1962), New York.

Webster's Ninth New Collegiate Dictionary (1983), p. 458.

World Commission on Environment and Development: Our Common Future (1987), Oxford University Press, New Haven, pp. 2-10. 